\title{
Karl Barth and the Belhar Confession
}
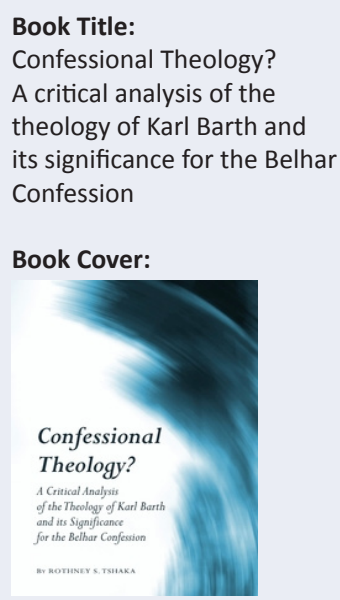

Author:

Rothney S. Tshaka

ISBN:

1-4438-2165-9

978-1-4438-2165-0

Publisher:

Cambridge Scholars

Publishing, Newcastle, 2010,

271 p., \$59.99*

*Book price at time of review

Review Title:

Karl Barth and the Belhar

Confession

Reviewer:

Vuyani S. Vellem ${ }^{1}$

\section{Affiliation:}

${ }^{1}$ Department Dogmatics and

Christian Ethics, University of

Pretoria, South Africa

Email:

vuyani.vellem@up.ac.za

\section{Postal address:}

Private Bag X20, Hatfield,

Pretoria 0002, South Africa

How to cite this book

review:

Vellem, V.S., 2012, 'Karl Barth and the Belhar Confession', Verbum et Ecclesia 33(1), Art. \#553, 2 pages. http://dx.doi. org/10.4102/ve.v33i1.553

(C) 2012. The Authors. Licensee: AOSIS OpenJournals. This work is licensed under the Creative Commons Attribution License.
This book is divided into five chapters, excluding the introduction and its appendices. It is a publication of a PhD thesis which poses a question about confessional theology, itself a pertinent question for our times - both in South Africa and in the world. The author equally makes this point when he says, 'confessional theology is the most likely theological pattern' for our times (p. 183).

The first three chapters delve into Karl Barth's theology. On page 49 the author presents one of his central arguments - that emphasis on the Word by Karl Barth should be understood to be instanced by Barth's rejection of liberal theology. This is the cornerstone to the argument of the book, which examines the relationship between confession and politics. The book's thesis that 'a relationship between confession and politics is unavoidable, yet this relationship is only best comprehended when one looks at it in a confessional manner' (p. xiii), is anchored on the notion of the supremacy of the Word of God traced from Karl Barth's theology. In this section of the book, the author succeeds in offering an excellent presentation of Karl Barth's theology and its pertinent themes for confessional theology, particularly the view of the Church Dogmatics and the Barmen Declaration as confessional theology in action.

Interesting arguments follow in Chapter Four where the author appropriates his study of Karl Barth by engaging the Belhar Confession 'in a changed and changing South African context' (p. 183). A definition of confessional theology is offered. Accordingly, confessional theology purportedly accentuates the 'centrality of the Word of God and acknowledges the essence of the church, its public witness of Jesus Christ to the world, the significance of the context in which this theology is done, as well as the ethics which is always implied in it,' (p. 184). The author employs Barmen and Barth's Dogmatics to affirm the Belhar Confession (p. 186). On page 219, clarity on the characteristics of confessional theology is given and enumerated to include:

- the supremacy of the Word of God

- confession as a confession for the church

- the public nature of a confession

- its contextual nature

- ethics

- awareness to change or changing circumstances.

The author further points to the link between apartheid and theology in South Africa. He argues that there was an evolution of what he calls 'theologized politics' (pp. 190-200), asserting that theology was added later in the development of apartheid. He indicts N. Diederichs' ideas on Afrikaner nationhood as the basis for what eventually developed into apartheid in South Africa. Leading up to the notion of the Status Confessionis, which anchors the arguments the author makes for the Belhar Confession, his treatment of South African theology, particularly Black theology as a response to the theological justification of apartheid is quite fascinating. The main point he makes is that the confessing church did not take root in South Africa because of Black Theology. He says that:

taking its point of departure not from the situation of the individual or a group, but from the Word of God as it is revealed to us in scripture, confessional theology remains consistently perturbed by any attempt to uncritically associate itself either with Afrikaner theology, black theology or for that matter, contextual theology. (p. 209)

Of course, including the statement cited above, there are aspects that inevitably attract some curiosity in the arguments that are presented in the book. Let me point to only two of them. Firstly, the notion of the Word of God can hardly escape ideological trappings in the same way as there is hardly any form of theology that can escape ideology. For example, the assertion on page 210 that Confessional theology's uniqueness derives from its departure from the Word of God rather than from the situation of the human being might require answering whether there is any possible grasp of the Word of God without experience which is central to any theology. Secondly, it might have 
been fruitful had the link between Barmen and James Cones's development of Black Theology been explored.

If Black Theology of liberation, as developed by James Cone, engaged the Barmen Declaration, Karl Barth's theology for that matter, then confessional theology as developed by the author could have been broadened and different perhaps.
The debates in this book are relevant to the unity of the Dutch Reformed Churches in South Africa, but also the discourse of WARC's Accra Confession. This book is recommended for those interested in the theological debate of the link between theology and politics, confession and public life. It is not only relevant to South Africa, but to the whole world too. 